\title{
Sutures modified by incorporation of chlorhexidine and cinnamaldehyde: anti-Candida effect, bioavailability and mechanical properties
}

Suturas modificadas pela incorporação de clorexidina e cinamaldeído: efeito anti-Candida, biodisponibilidade e propriedades mecânicas

\author{
Raphael Cavalcante COSTA ${ }^{a}(\mathbb{D})$, Yuri Wanderley CAVALCANTI ${ }^{\mathrm{D}}$, Ana Maria Gondim VALENÇA ${ }^{\mathrm{b}} \mathbb{( D}^{-}$, \\ Leopoldina de Fátima Dantas de ALMEIDA ${ }^{\text {b* }}$ \\ a UNICAMP - Universidade Estadual de Campinas, Faculdade de Odontologia de Piracicaba, Departamento de Prótese \\ e Periodontia, Piracicaba, SP, Brasil \\ b UFPB - Universidade Federal da Paraíba, Centro de Ciências da Saúde, Departamento de Clínica e Odontologia \\ Social, João Pessoa, PB, Brasil
}

\begin{abstract}
How to cite: Costa RC, Cavalcanti YW, Valença AMG, Almeida LFD. Sutures modified by incorporation of chlorhexidine and cinnamaldehyde: anti-Candida effect, bioavailability and mechanical properties. Rev Odontol UNESP. 2019;48:e20190042. https://doi.org/10.1590/1807-2577.04219.
\end{abstract}

\begin{abstract}
Resumo
Introdução: Fios de suturas com antimicrobianos são uma alternativa terapêutica para o controle de infecções orais. Objetivo: Incorporar Clorexidina (CHX) e Cinamaldeído (CN) em fios de sutura e avaliar o efeito anti-Candida, liberação de antimicrobianos e as propriedades mecânicas. Material e método: Fios de Seda (S) e Poliglactina 910 (P) foram seccionadas assepticamente $(20 \mathrm{~mm})$ e imersos para incorporação em CHX a $0,12 \%$, CN a $0,4 \%$ e solução fisiológica a $0,9 \%$ sob agitação por 60 minutos ( $\mathrm{n}=10 /$ grupo). Suspensões de $500 \mu \mathrm{L}$ de Candida albicans (ATCC 90028/1 × $106 \mathrm{UFC} / \mathrm{mL}$ ) foram utilizadas para avaliar a aderência fúngica após o período de 48 horas a $37^{\circ} \mathrm{C}$. A liberação de CLX e CN foi avaliada em 0,24 e 48 horas ( $\mathrm{n}=3$ / grupo) por espectrofotômetro UV-VIS $(275 \mathrm{~nm})$. A resistência à tração e o deslocamento $(\mathrm{n}=$ 5 / grupo) foram avaliados após a incorporação ( $30 \mathrm{~mm} / \mathrm{min}, 50 \mathrm{~N})$. Os dados foram analisados por Anova e Tukey $(\alpha=5 \%)$. Resultado: Não foi observado efeito anti-Candida nas suturas S e P incorporadas com CLX e CN $(\mathrm{p}>0,05)$. No entanto, a liberação progressiva foi verificada até 48 após o tratamento com CLX $(\mathrm{S}=0,075 / \mathrm{P}=0,073 \mu \mathrm{g} / \mathrm{mL})$ e $\mathrm{CN}(\mathrm{S}=35,33 / \mathrm{P}=5,72 \mu \mathrm{g} / \mathrm{mL})$. Houve uma diminuição na resistência à tração em S (CLX = 9,9/ CN = 9,9 N) e P (CLX = 14,4 / CN = 15,5 N) ( $<<0,05)$. Não foram observadas diferenças para o deslocamento para $\mathrm{S}(\mathrm{CLX}=19,3 / \mathrm{CN}=20,7 \mathrm{~mm})$ e $\mathrm{P}(\mathrm{CLX}=16,2 / \mathrm{CN}=15,8 \mathrm{~mm})(\mathrm{p}>0,05)$. Conclusão: A incorporação de $\mathrm{CLX}$ e $\mathrm{CN}$ não teve efeito positivo sobre as propriedades biológicas e mecânicas das suturas avaliadas.
\end{abstract}

Descritores: Suturas; Candida albicans; libertação de drogas; resistência à tração.

\begin{abstract}
Introduction: Antimicrobial sutures are a therapeutic alternative for the control of oral infections. Objective: Incorporate Chlorhexidine (CHX) and Cinnamaldehyde (CN) in sutures and evaluate the anti-Candida effect, release of antimicrobials and mechanical properties. Material and method: Silk (S) and Polyglactin 910 (P) sutures were aseptically sectioned $(20 \mathrm{~mm}$ ) and immersed for incorporation in $0.12 \%$ CHX, $0.4 \%$ $\mathrm{CN}$ and $0.9 \%$ saline solutions under stirring for 60 minutes $(\mathrm{n}=10 /$ group). Suspensions of $500 \mu \mathrm{L}$ of Candida albicans (ATCC 90028/ $1 \times 10^{6} \mathrm{CFU} / \mathrm{mL}$ ) were used to evaluate fungal adhesion after the $48 \mathrm{~h}$ period at $37^{\circ} \mathrm{C}$. The release of CLX and $\mathrm{CN}$ were evaluated at 0,24 and 48 hours ( $\mathrm{n}=3 /$ group) by UV-VIS spectrophotometer $(275 \mathrm{~nm})$. The tensile strength and displacement ( $\mathrm{n}=5 /$ group) were evaluated after incorporation $(30 \mathrm{~mm} / \mathrm{min}, 50 \mathrm{~N})$. Data were analyzed by Anova and Tukey $(\alpha=5 \%)$. Result: No antiCandida effect was observed on S and P sutures incorporated with CLX and CN (p>0.05). However, progressive release was verified up to 48 after treatment with CLX (S $=0.075 / \mathrm{P}=0.073 \mu \mathrm{g} / \mathrm{mL})$ and CN (S $=35.33 / \mathrm{P}=5.72 \mu \mathrm{g} / \mathrm{mL})$. There was a decrease in tensile strength in $\mathrm{S}(\mathrm{CLX}=9.9 / \mathrm{CN}=9.9 \mathrm{~N})$ and $\mathrm{P}(\mathrm{CLX}$
\end{abstract}


$=14.4 / \mathrm{CN}=15.5 \mathrm{~N})(\mathrm{p}<0.05)$. No differences were observed for the displacement for $\mathrm{S}(\mathrm{CLX}=19.3 /$ $\mathrm{CN}=20.7 \mathrm{~mm})$ and $\mathrm{P}(\mathrm{CLX}=16.2 / \mathrm{CN}=15.8 \mathrm{~mm})(\mathrm{p}>0.05)$. Conclusion: The incorporation of CLX and CN did not have a positive effect on the biological and mechanical properties of the sutures evaluated.

Descriptors: Sutures; Candida albicans; drug liberation; tensile strength.

\section{INTRODUCTION}

Surgical wound repair is a complex physiological process that includes inflammation, cell proliferation, matrix deposition and tissue remodeling ${ }^{1}$. Sutures are materials of first choice for the synthesis of these surgical sites because they exert less influence in the healing stages and promote tissue repair by first intention ${ }^{2}$. The main problem with surgical sutures is the deposition of biofilm on the surface and direct contact with the wound, increasing the risk of surgical site infections and altering the quality of the scar tissue ${ }^{3}$.

Surgical incisions in the oral cavity are even more vulnerable to infections, occurring in 2 to $12 \%$ of surgeries ${ }^{2,4}$. Some factors, such as the diversity of microorganisms, the presence of saliva, rich vascularization, contamination by food residues and trauma resulting from speech and hygiene increase the inflammatory process, the healing time and the discomfort of the patient ${ }^{5}$. In addition, removal of the suture in infectious areas may lead to bacteremia which is a risk factor for the development of bacterial endocarditis in high-risk patients ${ }^{6}$.

The oral mucosa when covered by acrylic surfaces of dental prostheses as in pre-prosthetic, peri-implant or immediate rehabilitation surgeries also becomes susceptible to fungal infections 7 . Candida albicans is the main pathogen involved in oral fungal infections due to the ability to colonize biotic and abiotic surfaces, promoting epithelial invasion, and may lead to systemic complications, mainly in immunosuppressed patients ${ }^{8}$. The interaction of bacteria and Candida inside biofilms is increasingly proven ${ }^{7,9}$, however, the role of fungi in the progression of inflammation and in the prognosis of oral infections remains uncertain.

In the literature, in vitro studies $2,3,10$, in vivo ${ }^{11,12}$ and clinical trials ${ }^{13,14}$ analyzed the adherence of bacteria present in the oral cavity in sutures. Moreover, there are not still studies that considered the adhesion of $\mathrm{C}$. albicans and the antifungal effect of coatings on surgical sutures under conditions that simulate the oral environment.

In addition, many studies have proposed various methods to develop antimicrobial sutures by using antimicrobial agents ${ }^{15,16}$. Cinnamaldehyde $\left(\mathrm{C}_{9} \mathrm{H}_{8} \mathrm{O}\right)$, a phytoconstituent extracted from cinnamon essential oil, has demonstrated antibacterial and antifungal effects in previous studies with cell viability assays 17,18 and reduced cytotoxicity in epithelial models of oral mucosa9. The use of cinnamaldehyde is considered a promising alternative for the control of the C. albicans biofilm, and for this reason the incorporation of this antimicrobial into sutures could be a viable alternative for use in oral surgeries in areas prone to infections and this association not been yet investigated.

Therefore, the aim of this study was to perform the incorporation of chlorhexidine and cinnamaldehyde into sutures and to evaluate the anti-Candida effect, the release of these antimicrobials and the influence of this incorporation on the mechanical properties of the sutures.

\section{MATERIAL AND METHOD}

\section{Preparation and Incorporation of the Samples}

The schematic diagram shows of the experimental design this study (Scheme 1). Two groups of sutures were used synthetic biodegradable - Polyglactin 910 (Vicryl-rapid ${ }^{\circledR}$, Ethicon, USA) and 
other nonbiodegradable - Silk (Seda-Silk ${ }^{\circledR}$, Ethicon, USA) with same thickness and quantity of filaments (3.0). These materials were selected because they are the most used in oral surgeries. The antimicrobial substances used for incorporation into the sutures were Chlorhexidine Gluconate $0.12 \%$ (PerioGard ${ }^{\circledR}$, Colgate-Palmolive, New York, USA) and Cinnamaldehyde $0.4 \%$ (Sigma-Aldrich ${ }^{\circledR}$, São Paulo, Brazil) as specified in Table 1.

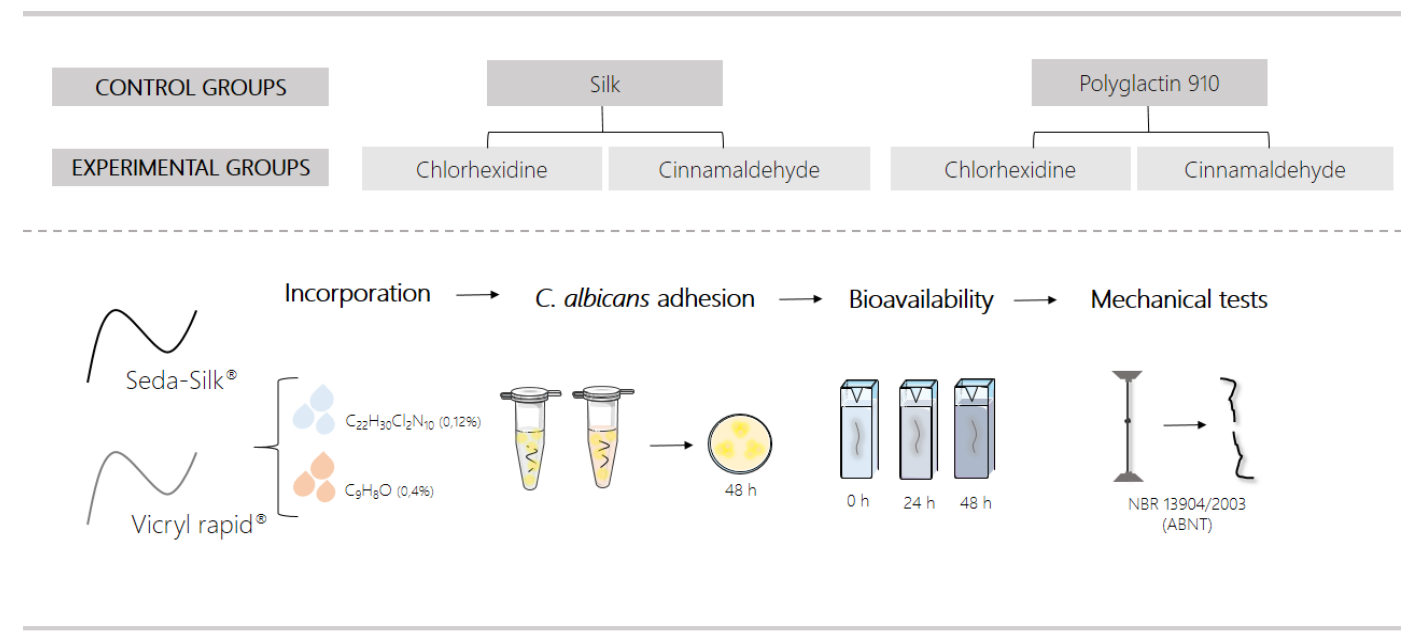

Scheme 1. Schematic diagram of the experimental design ${ }^{19}$.

Table 1. Morphological and commercial characterization of the sutures and substances evaluated

\begin{tabular}{ccccc}
\hline Commercial name & Thickness & Material & Configuration & Lot number \\
\hline Seda-Silk $^{\mathrm{a}}$ & $3-0$ & Black Silk & Multifilamentado & AE0068 \\
Vicryl rapid $^{\mathrm{a}}$ & $3-0$ & Polyglactin 910 & Multifilamentado & 524605 \\
\hline Commercial name $^{\mathrm{C}}$ & Composition & Substance & Concentration & Lot number \\
\hline PerioGard $^{\mathrm{b}}$ & Liquid & Chlorhexidine Gluconate & $0.12 \%$ & $5030 \mathrm{BR} 121 \mathrm{~A}$ \\
Cinnamaldeido $^{c}$ & Liquid & Cinnamaldehyde & $0.4 \%$ & MFCD00007000 \\
\hline
\end{tabular}

aEthicon US LLC ${ }^{\circledR}$, Cincinnati, USA ${ }^{20}$; bColgate-Palmolive Company ${ }^{\circledR}$, New York, USA ${ }^{21}$; cSigma-Aldrich $^{\circledR}$, São Paulo, Brazil $^{22}$

The silk and polyglactin 910 sutures were sectioned in $20 \mathrm{~mm}$ length samples under aseptic conditions and with tweezers, scissors and sterile millimeter ruler. Subsequently, the samples were immersed in $500 \mu \mathrm{l}$ of the test-solutions ${ }^{15}$. These samples were separately deposited in $0.12 \%$ chlorhexidine, $0.4 \%$ cinnamaldehyde and $0.9 \%$ saline solution (control), remaining under stirring on a vibratory table for 60 minutes for homogeneous incorporation of the substances in all parts.

\section{Anti-Candida albicans Effect}

After incorporation, the samples ( $\mathrm{n}=30$ /group) were inserted into $500 \mu \mathrm{L}$ of brain and heart infusion broth (BHI Broth, Difco ${ }^{\circledR}$, Rio de Janeiro, RJ, Brazil) with a suspension of $C$. albicans (ATCC 90028) standardized at the optical density of 0.1 to $600 \mathrm{~nm}$, equivalent to $1 \times 10^{6}$ colony forming units per milliliter ( $\mathrm{CFU} / \mathrm{mL}$ ). Then the samples were incubated in aerobiose at $37^{\circ} \mathrm{C}$ for a period of 48 hours. After incubation, the samples were removed immersed in saline solution and shaken for 30 seconds in vortex (Phoenix ${ }^{\circledR}$, São Paulo, SP, Brazil) for the detachment of cells adhered to the sutures. Serial dilutions $\left(10^{-1}\right.$ to $\left.10^{-5}\right)$ were performed for further evaluation of cell viability by the drop technique. Subculture of the serial dilutions was performed on Saburaund agar plates (Difco ${ }^{\circledR}$, Rio de Janeiro, RJ, Brazil) and the number of viable microorganisms was determined after 
$24 \mathrm{~h}$ of incubation. All microbiological assays were performed in triplicate in three independent experiments.

\section{Antimicrobial Release}

The samples ( $\mathrm{n}=9$ /group) were distributed in a 24-well plate for cell culture (Zellkultur Testplatte 24®; Trasadingen, Switzerland) containing $1 \mathrm{ml}$ of $0.9 \% \mathrm{NaCl}$. The release was measured by the analysis of the change in optical density obtained by divided beam UV/Vis spectrometry (BioDrop ${ }^{\circledR}$, São Paulo, Brazil), using a wavelength of $275 \mathrm{~nm}$, with volume of $2 \mu \mathrm{L}$, and readings were taken immediately after the incorporation $\left(\mathrm{t}_{0}\right)$ and after 24 hours $\left(\mathrm{t}_{1}\right)$ and 48 hours $\left(t_{2}\right)$. Based on previously established linear calibration, the amount of antimicrobial $(\mu \mathrm{g})$ released in each $1 \mathrm{~mL}$ was measured $(\mu \mathrm{g} / \mathrm{mL})$. The assays were performed in triplicate to verify the highest release peaks of the incorporated agents.

\section{Mechanical Tests}

The samples ( $\mathrm{n}=5$ /group) were submitted to mechanical tests of tensile strength on node pull and displacement after incorporation with antimicrobials. The parameters described in standard NBR 13904:2003 ${ }^{19}$ of the Brazilian Association of Technical Standards (ABNT) were followed for mechanical tests and control of traction results. The analyzes were performed in a universal machine of mechanical tests (Shimadzu ${ }^{\circledR}$, Kyoto, Japan) with a speed of $30 \mathrm{~mm} / \mathrm{min}$ and a load cell of $50 \mathrm{~N}$ (Recommended parameters for 3.0 diameter sutures). A previously trained researcher, according to standardization, reproduced a surgical node and, later, the wire was positioned in the machine. Initially, the knot was positioned equidistant from the claws, with the ends making 3 turns around the fixing cylinder, establishing a distance of $50 \mathrm{~cm}$ between them. In this condition, the device was activated generating force $(\mathrm{N})$ and displacement $(\mathrm{mm})$ values until the wire broke. These parameters were evaluated to verify the influence of the treatment on surgical node rupture (tensile strength) and manipulation and dehiscence of the sutures (displacement).

\section{Data Analysis}

The data were analyzed by statistical software SPSS (IBM SPSS Statistics v. 21.0; IBM-Corp). The variables were submitted to the normality and homoscedasticity test (Shapiro-Wilk; $\alpha=5 \%$ ). The tested sutures present specific clinical indications and for this reason the analysis of variance (ANOVA 1-way; $\alpha=5 \%$ ) was used only for intra-group comparison of the effect of the incorporated substances (chlorhexidine and cinnamaldehyde) in the UFC (C. albicans) data, the tensile strength and the displacement of each group. Tukey test (HSD) was used as a post hoc for multiple paired comparison $(\alpha=5 \%)$. The antimicrobial release was analyzed descriptively.

\section{RESULT}

In the analysis of fungal cell viability (CFU/mL), there was no difference in the adhesion of C. albicans on silk and polyglactin 910 sutures incorporated with chlorhexidine and cinnamaldehyde in relation to their respective controls ( $p>0.05$ ) (Figure 1). 


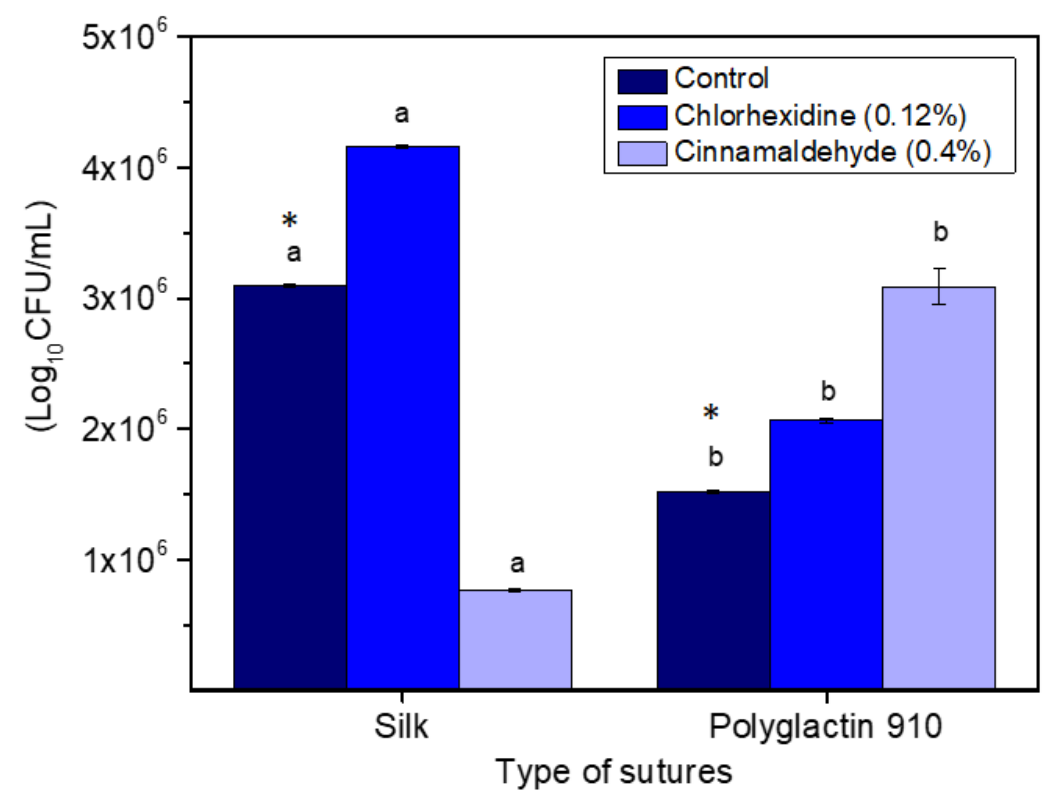

Figure 1. Colony forming units $\left(\log _{10} \mathrm{CFU} / \mathrm{mL}\right)$ of sutures incorporated with antimicrobials. *Non-significant differences $(p>0.05)$.

With regard to the release of antimicrobials, these were incorporated and presented constant and increasing release in the periods evaluated, with higher release peaks after 48 hours of incorporation. For both materials (Silk and Polyglactin 910), the released cinnamaldehyde concentrations were higher when compared to the chlorhexidine concentration in the respective groups and evaluation periods (Figure 2).

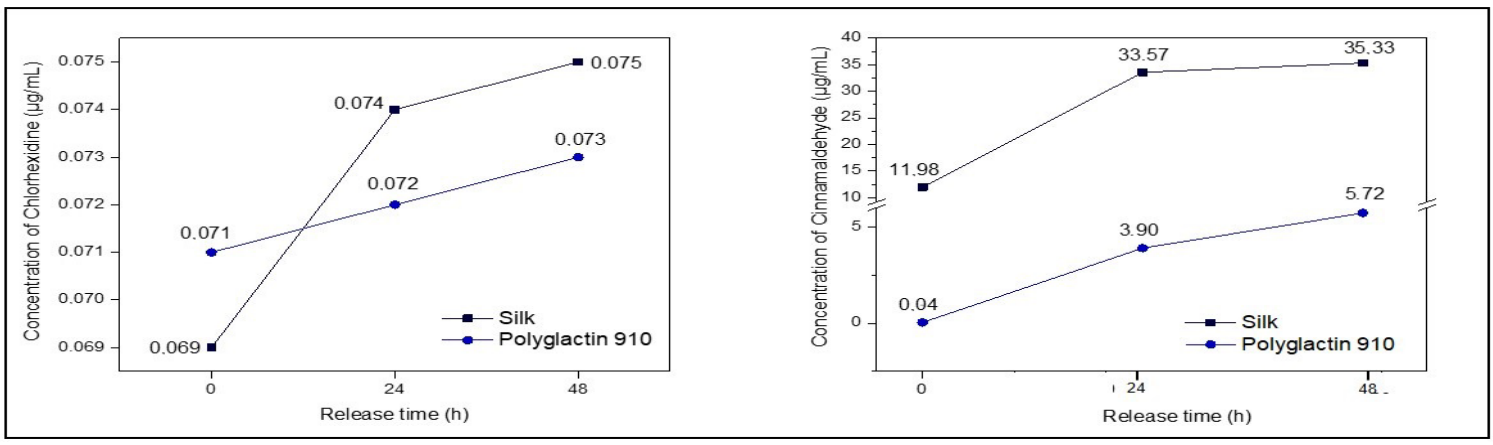

Figure 2. Graphical distribution of the release of chlorhexidine $0.12 \%$ and cinnamaldehyde $0.4 \%$ in 0,24 and 48 hours after incorporation into silk (S) and polyglactin $910(\mathrm{P})$ sutures.

The mechanical tests demonstrated a reduction of the rupture force after incorporation of the antimicrobials to the sutures when compared with the respective control groups $(p<0.05)$. However, displacement values were not influenced by incorporation, with no difference between chlorhexidine and cinnamaldehyde for Silk and Polyglactin 910 ( $p>0.05$ ) (Table 2).

Table 2. Tensile strength (mean and standard deviation) and displacement of sutures after incorporation with antimicrobials 


\begin{tabular}{|c|c|c|c|c|c|c|}
\hline \multicolumn{7}{|c|}{ Experimental groups } \\
\hline & \multicolumn{3}{|c|}{ Silk (S) } & \multicolumn{3}{|c|}{ Polyglactin $910(\mathrm{P})$} \\
\hline & Control & $\begin{array}{c}\text { Chlorhexidine } \\
0.12 \%\end{array}$ & $\begin{array}{c}\text { Cinnamaldehyde } \\
0.4 \%\end{array}$ & Control & $\begin{array}{c}\text { Chlorhexidine } \\
0.12 \%\end{array}$ & $\begin{array}{c}\text { Cinnamaldehyde } \\
0.4 \%\end{array}$ \\
\hline $\begin{array}{c}\text { Tensile } \\
\text { strength } \\
\text { (N) }\end{array}$ & $13.3^{A^{*}}$ & $9.9 \pm 0.4^{\mathrm{B}}$ & $9.9 \pm 0.4^{\mathrm{B}}$ & $17.7^{\mathrm{C}}$ & $14.4 \pm 0.7 \mathrm{D}$ & $15.5 \pm 0.4^{\mathrm{D}}$ \\
\hline $\begin{array}{l}\text { Displacement } \\
\text { ( } \mathrm{mm})\end{array}$ & $-* *$ & $19.3 \pm 1.7$ & $20.7 \pm 3.3$ & - & $16.2 \pm 1.3$ & $15.8 \pm 1.2$ \\
\hline
\end{tabular}

*Similar capital letters on the same line indicate statistically significant values $(\mathrm{p}<0.05)$; ${ }^{* *}$ Reference values for displacement tests are missing from ABNT standard (NBR 13904:2003) ${ }^{19}$.

\section{DISCUSSION}

The present study demonstrated that it is possible to incorporate antimicrobials into sutures by the immersion method with constant release of the substances for up to 48 hours. Different from other studies it was considered the indication of the material and the time required for incorporation, availability and adhesion of the C. albicans biofilm, in order to simulate an oral clinical condition. In addition, it is the first study that to use cinnamaldehyde as a possible clinical alternative in preoperative antisepsis of sutures to be used at surgical sites susceptible to fungal infections.

In view of the peculiarities of the oral cavity and the absence of an ideal suture the use of antimicrobial solutions for mouthwash is among the main postoperative recommendations ${ }^{2}$. Chlorhexidine gluconate $(0.12 \%)$ is the most indicated antimicrobial because it has a broad spectrum of action ${ }^{6,15}$. However, the dose-response effect through indiscriminate use may affect the viability of epithelial cells and fibroblasts, interfering in the regulation of proinflammatory cytokines and growth factors, contradictorily, hindering tissue repair and increasing the resistance of microorganisms ${ }^{23}$. For this reason, it is believed that the previous incorporation of antimicrobials into surgical sutures is a promising alternative in the control of adhesion and biofilm formation because it allows controlled release for a longer period of time and with less toxic effect.

In this study, chlorhexidine and cinnamaldehyde incorporated into sutures were not able to exert anti-Candida effect. One possible explanation for this result is the chemical interaction that may have occurred between the antimicrobials tested and the synthetic components used in prefabricated coatings of the sutures inactivating their effect as demonstrated in other studies ${ }^{4,24}$. The incorporation of substances into sutures by the immersion method is a technique used for ease of execution, rapid incorporation and low cost when compared to other coating techniques but that may also have influenced these results. In addition, biofilms of $C$. albicans present more organized and complex structures than bacterial biofilms, which hinders the penetration of substances and their possible antimicrobial effect in small doses ${ }^{7}$.

Regarding bioavailability, chlorhexidine and cinnamaldehyde were absorbed by the sutures and released gradually at low concentrations over 48 hours. Similar results on the kinetics of progressive release are demonstrated in the literature only for chlorhexidine for 48 hours ${ }^{15,16}$. This time is strategic for antimicrobial sutures that impede the infectious process without selecting resistant microorganisms ${ }^{3}$. The low concentrations of the released substances may be, according to cell viability studies ${ }^{15,16,25}$, considered to be biocompatible with oral tissues for chlorhexidine and cinnamaldehy because they are below $11 \mu \mathrm{g} / \mathrm{cm}$ and $65 \mu \mathrm{g} / \mathrm{mL}$, respectively. This is a relevant finding in this study because it demonstrates the possibility of incorporation of 
controlled release antimicrobials with low concentration for long times through this coating technique.

After the incorporation, a reduction in tensile strength of the sutures was observed. However, the values evidenced in the present study are still higher than others reported in the literature that tested silk sutures without incorporation ${ }^{26}$ and polyglactin $910^{27}$. This fact reaffirms that external aspects such as storage conditions, manufacturing time and types of materials can influence this parameter ${ }^{26,28}$. Another point is that the incorporation of the antimicrobial agents did not influence the displacement of the sutures, which clinically may not have a negative effect on the elasticity and plasticity of the sutures. In addition, it is necessary to also analyze the impact of saliva on these properties.

This study presents some limitations because it is an in vitro assay, however, we emphasize that these results may guide future research for the synthesis of new antimicrobial coatings with a focus on fungal infections. Other studies should be carried out by increasing the concentration of antimicrobials and reducing the time of exposure, seeking an effective antifungal effect that exerts less influence on the physical structure of the sutures. In summary, we believe that the treatment proposed in this study presents a promising alternative for surgical sutures to allow the incorporation and controlled release of antimicrobials. Nevertheless, this treatment requires preliminary alterations before use in clinical practice.

\section{CONCLUSION}

The incorporation of chlorhexidine and cinnamaldehyde into sutures showed no anti-Candida effect, even with the progressive release of antimicrobials with greater bioavailability after 48 hours of incorporation. In addition, the incorporation adversely interfered in the tensile strength without influencing the displacement of the sutures. Thus, there is no increase in the effectiveness of surgical sutures incorporated with antimicrobials the biological and mechanical properties evaluated.

\section{ACKNOWLEDGEMENTS}

The authors express their gratitude to the Solidification Laboratory, Technology Center (UFPB) for providing the equipment and facilitating the mechanical analysis in this study. The authors also thank the National Council for Scientific and Technological Development (CNPq) for granting the scholarship of the first author (process number \#407394/2016-8).

\section{REFERENCES}

1. Selvi F, Cakarer S, Can T, Kirli Topcu Sİ, Palancioglu A, Keskin B, Bilgic B, Yaltirik M, Keskin C. Effects of different suture materials on tissue healing. J Istanb Univ Fac Dent. 2016 Jan 12;50(1):35-42. http://dx.doi.org/10.17096/jiufd.79438. PMid: 28955553.

2. Costa OC No, Lobo LA, Iorio NL, Vasconcelos MFC, Maia LC, Tannure PN, et al. Oral bacteria adherence to suture threads: an in vitro study. Oral Maxillofac Surg. 2015 Sep;19(3):275-80. http://dx.doi.org/10.1007/s10006-015-0487-4. PMid:25711725.

3. Reinbold J, Uhde AK, Müller I, Weindl T, Geis-Gerstorfer J, Schlensak C, et al. Preventing surgical site infections using a natural, biodegradable, antibacterial coating on surgical sutures. Molecules. 2017 Sep;22(9):E1570. http://dx.doi.org/10.3390/molecules22091570. PMid:28925959.

4. Venema S, Abbas F, van de Belt-Gritter B, van der Mei HC, Busscher HJ, van Hoogmoed CG. In vitro oral biofilm formation on triclosan-coated sutures in the absence and presence of additional antiplaque 
treatment. J Oral Maxillofac Surg. 2011 Apr;69(4):980-5.

http://dx.doi.org/10.1016/j.joms.2010.02.030. PMid:20674122.

5. Alencar CRB, de Andrade FJP, Catão MHCV. Cirurgia oral em pacientes idosos: considerações clínicas, cirúrgicas e avaliação de riscos. RSBO Revista Sul-Brasileira de Odontologia. 2011 Jun;8(2):200-10.

6. Sethi KS, Karde PA, Joshi CP. Comparative evaluation of sutures coated with triclosan and chlorhexidine for oral biofilm inhibition potential and antimicrobial activity against periodontal pathogens: an in vitro study. Indian J Dent Res. 2016 Sep-Oct;27(5):535-9. http://dx.doi.org/10.4103/0970-9290.195644. PMid:27966513.

7. Cavalcanti YW, Morse DJ, da Silva WJ, Del-Bel-Cury AA, Wei X, Wilson M, et al. Virulence and pathogenicity of Candida albicans is enhanced in biofilms containing oral bacteria. Biofouling. 2015;31(1):27-38. http://dx.doi.org/10.1080/08927014.2014.996143. PMid:25574582.

8. Boonstra JM, van der Elst KC, Veringa A, Jongedijk EM, Brüggemann RJ, Koster RA, et al. Pharmacokinetic properties of micafungin in critically ill patients diagnosed with invasive candidiasis. Antimicrob Agents Chemother. 2017 Nov 22;61(12):pii: e01398-17. http://dx.doi.org/10.1128/AAC.01398-17. PMid: 28971861.

9. Morse DJ, Wilson MJ, Wei X, Lewis MAO, Bradshaw DJ, Murdoch C, et al. Denture-associated biofilm infection in three-dimensional oral mucosal tissue models. J Med Microbiol. 2018 Mar;67(3):364-75. http://dx.doi.org/10.1099/jmm.0.000677. PMid:29458673.

10. Marzo G, Loffredi R, Marchetti E, Di Martino S, Di Pietro C, Marinelli G. In vitro antibacterial efficacy of Vicryl Plus suture (coated Polyglactin 910 with triclosan) using zone of inibition assays. Oral Implantol (Rome). 2008 Apr;1(1):43-8. PMid:23285335.

11. Pelz K, Tödtmann N, Otten JE. Comparison of antibacterial-coated and non-coated suture material in intraoral surgery by isolation of adherent bacteria. Ann Agric Environ Med. 2015;22(3):551-5. http://dx.doi.org/10.5604/12321966.1167733. PMid:26403133.

12. Pons-Vicente O, López-Jiménez L, Sánchez-Garcés MA, Sala-Pérez S, Gay-Escoda C. A comparative study between two different suture materials in oral implantology. Clin Oral Implants Res. 2011 Mar;22(3):282-8. http://dx.doi.org/10.1111/j.1600-0501.2010.01993.x. PMid:21039893.

13. Cruz F, Leite F, Cruz G, Cruz S, Reis J, Pierce M, et al. Sutures coated with antiseptic pomade to prevent bacterial colonization: a randomized clinical trial. Oral Surg Oral Med Oral Pathol Oral Radiol. 2013 Aug;116(2):e103-9. http://dx.doi.org/10.1016/j.0ooo.2011.12.016. PMid:22841431.

14. Bucci M, Borgonovo A, Bianchi A, Zanellato A, Re D. Microbiological analysis of bacterial plaque on three different threads in oral surgery. Minerva Stomatol. 2016 Feb;66(1):28-34. http://dx.doi.org/10.23736/S0926-4970.16.03966-7. PMid:27583530.

15. Obermeier A, Schneider J, Wehner S, Matl FD, Schieker M, von Eisenhart-Rothe R, et al. Novel high efficient coatings for anti-microbial surgical sutures using chlorhexidine in fatty acid slow-release carrier systems. PLoS One. 2014 Jul 1;9(7):e101426. http://dx.doi.org/ 10.1371/journal.pone.0101426. PMid: 24983633.

16. Obermeier A, Schneider J, Harrasser N, Tübel J, Mühlhofer H, Pförringer D, et al. Viable adhered Staphylococcus aureus highly reduced on novel antimicrobial sutures using chlorhexidine and octenidine to avoid surgical site infection (SSI). PLoS One. 2018 Jan 9;13(1):e0190912. http://dx.doi.org/10.1371/journal.pone.0190912. PMid: 29315313.

17. Almeida LF, Paula JF, Almeida RV, Williams DW, Hebling J, Cavalcanti YW. Efficacy of citronella and cinnamon essential oils on Candida albicans biofilms. Acta Odontol Scand. 2016 Jul;74(5):393-8. http://dx.doi.org/10.3109/00016357.2016.1166261. PMid:27098375.

18. Chen W, Golden DA, Critzer FJ, Davidson PM. Antimicrobial activity of cinnamaldehyde, carvacrol, and lauric arginate against salmonella tennessee in a glycerol-sucrose model and peanut paste at different fat concentrations. J Food Prot. 2015 Aug;78(8):1488-95. http://dx.doi.org/10.4315/0362-028X.JFP14-599. PMid:26219362. 
19. ABNT: Associação Brasileira de Normas Técnicas. NBR 13904:2003- fios para sutura cirúrgica. Rio de Janeiro: ABNT; 2003.

20. Johnson \& Johnson Medical Devices Companies [Internet]. USA: Medical Devices Business Services, Inc.; 2019 [cited 2019 Apr 16]. Available from: www.ethicon.com

21. Colgate-Palmolive [Internet]. New York: Colgate-Palmolive Comercial Ltda; 2019 [cited 2019 Apr 16]. Available from: www.colgate.com.br

22. Merck [Internet]. São Paulo: Sigma-Aldrich Co.; 2019 [cited 2019 Apr 16]. Available from: www.sigmaaldrich.com

23. Sawada K, Fujioka-Kobayashi M, Kobayashi E, Schaller B, Miron RJ. Effects of antiseptic solutions commonly used in dentistry on bone viability, bone morphology, and release of growth factors. J Oral Maxillofac Surg. 2016 Feb;74(2):247-54. http://dx.doi.org/10.1016/j.joms.2015.09.029. PMid:26501425.

24. Faria RL, Cardoso LM, Akisue G, Pereira CA, Junqueira JC, Jorge AO, et al. Antimicrobial activity of Calendula officinalis, Camellia sinensis and chlorhexidine against the adherence of microorganisms to sutures after extraction of unerupted third molars. J Appl Oral Sci. 2011 Oct;19(5):476-82. http://dx.doi.org/10.1590/S1678-77572011000500007. PMid:21986652.

25. Wiwattanarattanabut K, Choonharuangdej S, Srithavaj T. In vitro anti-cariogenic plaque effects of essential oils extracted from culinary herbs. J Clin Diagn Res. 2017 Sep;11(9):DC30-5. http://dx.doi.org/10.7860/JCDR/2017/28327.10668. PMid:29207708.

26. Castro HL, Bona AD, Ávila VJB. Propriedades físicas dos fios de sutura usados na odontologia. Braz Dent Sci. 2010 Abr-Jun;10(2):85-90.

27. Rampat R, Jain S. The effect of commonly used surgical solutions on the tensile strength of sutures. J Pediatr Ophthalmol Strabismus. 2014 May-Jun;51(3):189-90. http://dx.doi.org/10.3928/0191391320140318-01. PMid:24654799.

28. Sardenberg T, Müller SS, Silvares PRA, Mendonça AB, Moraes RRL. Assessment of mechanical properties and dimensions of suture threads utilized in orthopedic surgeries. Acta Ortop Bras. 2003 Apr;11(2):88-94. http://dx.doi.org/10.1590/S1413-78522003000200004.

\section{CONFLICTS OF INTERESTS}

The authors declare no conflicts of interest.

\section{*CORRESPONDING AUTHOR}

Leopoldina de Fátima Dantas de Almeida, UFPB - Universidade Federal da Paraíba, Centro de Ciências da Saúde, Departamento de Clínica e Odontologia Social, Cidade Universitária, 58033455 João Pessoa - PB, Brasil, e-mail: leopoldinalmeida@hotmail.com

Received: April 16, 2019

Accepted: July 11, 2019 